\title{
Influence of Roof-Rack, Trailer etc. on Automobile Fuel Consumption and Exhaust Emissions, Measured on-the-road
}

Reprint from SAE Technical Paper Series, SP-1335, paper 980682, pp 285-289 (International Congress and Exposition, Detroit, USA, February 23-26, 1998)

Magnus Lenner

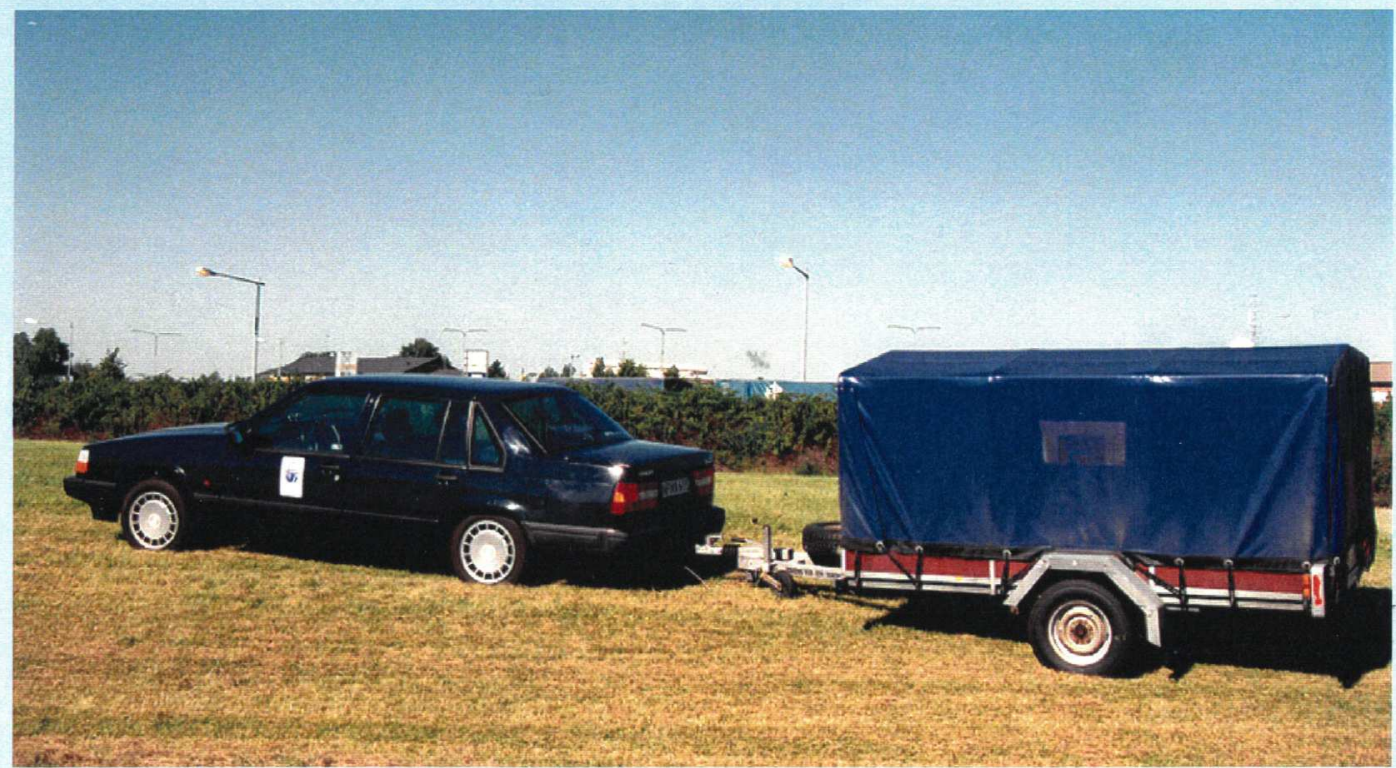




\title{
VTI särtryck $294 \cdot 1998$
}

\section{Influence of Roof-Rack, Trailer etc. on Automobile Fuel Consumption and Exhaust Emissions, Measured on-the-road}

\author{
Reprint from SAE Technical Paper Series, SP-1335, \\ paper 980682, pp 285-289 (International Congress and \\ Exposition, Detroit, USA, February 23-26, 1998) \\ Magnus Lenner
}




\title{
Influence of Roof-Rack, Trailer etc on Automobile Fuel Consumption and Exhaust Emissions, Measured on-the-road
}

\author{
Magnus Lenner \\ Swedish Road and Transport Research Institute
}

Reprinted From: General Emissions

(SP-1335) 
The appearance of the ISSN code at the bottom of this page indicates SAE's consent that copies of the papermaybe made forpersonal or internal use of specificclients. Thisconsent is given on the condition however, that the copier pay a $\$ 7.00$ per article copy fee through the Copyright Clearance Center, Inc. Operations Center, 222Rosewood Drive, Danvers, MA 01923 for copying beyond that permitted by Sections 107 or 108 of the U.S. Copyright Law. This consent does not extend to otherkinds of copying such as copying for general distribution, for advertising or promotional purposes, for creating new collective works, or for resale.

SAE routinely stocks printed papers for a period of three years following date of publication. Direct your orders to SAE Customer Sales and Satisfaction Department.

Quantity reprint rates can be obtained from the Customer Sales and Satisfaction Department.

To request permission to reprint a technical paper orpermission to use copyrighted SAE publications in other works, contact the SAE Publications Group.

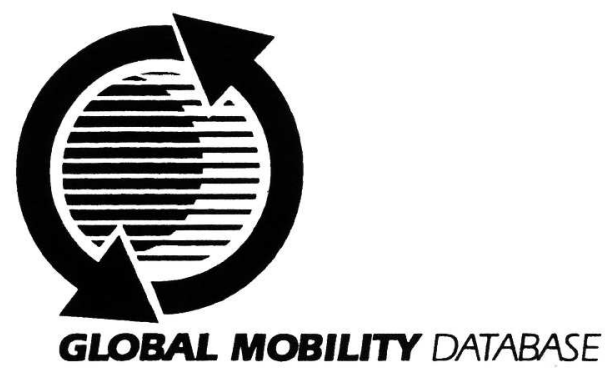

All SAE papers, standards, and selected books are abstracted and indexed in the SAE GlobalMobility Database.

Nopart of this publication mayby reproduced in any form, in an electronic retrieval system or otherwise, without the prior written permission of the publisher.

\section{ISSN0148-7191}

Copyright 1998 Society of Automotive Engineers, Inc.

Positions and opinions advanced in this paper are those of the author(s) and not necessarily those of SAE. The author is solely responsible for the content of the paper. A process is available by which discussions will be printed with the paper if it is published in SAE Transactions. For permission to publish this paper in full or in part, contact the SAE Publications Group.

Persons wishing to submitpapers to be considered forpresentation orpublication through SAE should send the manuscript or a 300 word abstract of a proposed manuscript to: Secretary, Engineering Meetings Board, SAE. 


\title{
Influence of Roof-Rack, Trailer etc on Automobile Fuel Consumption and Exhaust Emissions, Measured on-the-road
}

\author{
Magnus Lenner \\ Swedish Road and Transport Research Institute
}

Copyright (C) 1998 Society of Automotive Engineers, Inc.

\begin{abstract}
Fuel consumption, $\mathrm{NO}$ and $\mathrm{NO}_{x}$ were monitored using on board apparatus during road driving at constant speeds, for a gasoline passenger car with TWC. Exhaust gas concentrations (ppm) of nitrogen oxides were translated into mass emission values $(\mathrm{g} / \mathrm{km})$ by methods previously reported [1-4]. In addition to standard vehicle configuration, the experiments included driving with studded tyres, trailer, roof-rack and ski-box. Also, the influence of windy conditions was studied.
\end{abstract}

Generally speaking the use of extra equipment, and also higher speed, entailed raised fuel consumption. The $\mathrm{NO}_{x}$ emissions, however, did not exhibit a corresponding dependence. Calculated $\mathrm{NO}_{2} / \mathrm{NO}_{x}$ ratios $(\mathrm{v} / \mathrm{v})$ varied between 0.01 and 0.03 .

\section{INTRODUCTION}

Systematic studies of how environmental parameters related to the use of passenger cars are influenced by application of additional equipment is a hitherto sparsely investigated field, of vast interest in the creation of realistic emission models. Studies appearing in this area have typically concerned increased fuel consumption resulting from use of: light bars on police vehicles [5,6], different tyre types [7], roof-mounted luggage [8] or camping trailer [9].

Likewise crucial as a source of input data for emission modeling are studies during actual road driving, in realistic traffic conditions. That is because measurement and evaluation of the parameters which characterize automobile energy expenditure and exhaust emissions are traditionally performed as standardized procedures in an emission laboratory, the vehicle running on rollers in a chassis dynamometer. Studies from real traffic using on board measurement apparatus have been made at VW [2,3], at the Belgian research institute VITO [4] and at GM, Michigan [10]. Warren Spring Laboratory in England used a proportional sampler in combination with a "mini-CVS" $[11,12]$ which can be employed for on-board sampling and subsequent analysis. At the University of Denver
Stedman et al. [13] have developed FEAT, a remote sensing concept for roadside monitoring of pollutant concentrations in the exhaust plumes of passing vehicles. The FEAT method has been used extensively in Sweden $[14,15]$ and elsewhere.

\section{EXPERIMENTAL}

TEST VEHICLE AND SETUP - The vehicle used in the study was a 1992 Volvo 940 Sedan with a 2.3- $\iota$ B230FB engine and three-way catalyst having an odometer reading of approximately 100000 kilometres. The vehicle test weight was $1408 \mathrm{~kg}$ and the frontal area was $2.15 \mathrm{~m}^{2}$.

Measuring instruments, computer, data logger and associated peripherals were fitted inside the car.

Additional equipment - Standard Michelin Energy and studded Nord Frost tyres both of dimension 185/65 R 15 were used for the tests. Roof-rack and skibox (frontal area $0.25 \mathrm{~m}^{2}$ ) were common commercial products. The trailer was $4.3 \mathrm{~m}$ long by $2.2 \mathrm{~m}$ wide, designed for a maximum load of $940 \mathrm{~kg}$, and exposed 1.35 by $1.75 \mathrm{~m}\left(2.36 \mathrm{~m}^{2}\right)$ of frontal area to wind with a raised cover mounted.

Fuel flow metering - Fuel volume flows were registered by a Pierburg PLU $116 \mathrm{H}$ flow meter. The instrument has automatic corrections for fuel return flows, vapour locks and temperature differentials. The dynamic range is 0.4 - 60 litres per hour $(l / h)$.

NO measurement - An Eco Physics CLD 700 instrument based on chemiluminescence was used to measure nitrogen oxides. Volume concentrations of total nitrogen oxides $\left(\mathrm{NO}_{\mathrm{x}}\right)$ and nitrogen monoxide (NO) are monitored in parallel, enabling calculation, in a subtractive mode, of nitrogen dioxide $\left(\mathrm{NO}_{2}\right)$.

Data aquisition - The PC-based measuring system registers and stores sets of data on the computer hard disk at a frequency of $4 \mathrm{~Hz}$. The following parameters were logged. 
- Accumulated dist.

- Accumulated fuel

- Fuel temp.

- NO

- $\quad \mathrm{NO}_{x}$

- $\quad \mathrm{NO}_{2}$

- Oil temp.

- Water temp.

- Ambient temp.

TEST PROGRAM - A straight, even and horizontal stretch of highway was chosen for a test track. A single experiment consisted of six successive runs, three each way, at constant speed. For each run, data were collected during at least $1 \mathrm{~km}$ of driving at the preset speed. The trials took place at low-traffic hours, avoiding influence from other traffic.

Particulars about the various configurations of peripheral equipment investigated are given next. All experiments were run at 70,80 and $90 \mathrm{~km} / \mathrm{h}$.

Table 1. Details about the trials.

\section{No wind}

$\begin{aligned} \text { Test No. } & \text { Equipment } \\ 1 & \text { None (reference) } \\ 2 & \text { Tyre studs } \\ 3 & \text { Roof-rack } \\ 4 & \text { Ski-box } \\ 5 & \text { Trailer (T) } \\ 6 & \text { Trailer + Load (T+ } \\ 7 & \text { Trailer + Cover (T } \\ 8 & \text { Trailer + Load + Cov } \\ \text { Wind } & \\ 9 & \text { None (reference) } \\ 10 & \text { Tyre studs } \\ 11 & \text { Roof-rack } \\ 12 & \text { Ski-box }\end{aligned}$

In experiments 6 and 8 the load applied was $564 \mathrm{~kg}, 60 \%$ of full trailer load capacity $(940 \mathrm{~kg})$. The empty trailer weighed $310 \mathrm{~kg}$. During experiments 9 through 12 the test road was exposed to roughly $4 \mathrm{~m} / \mathrm{s}$ side wind. Figures 1 through 4 picture some of the experimental configurations.

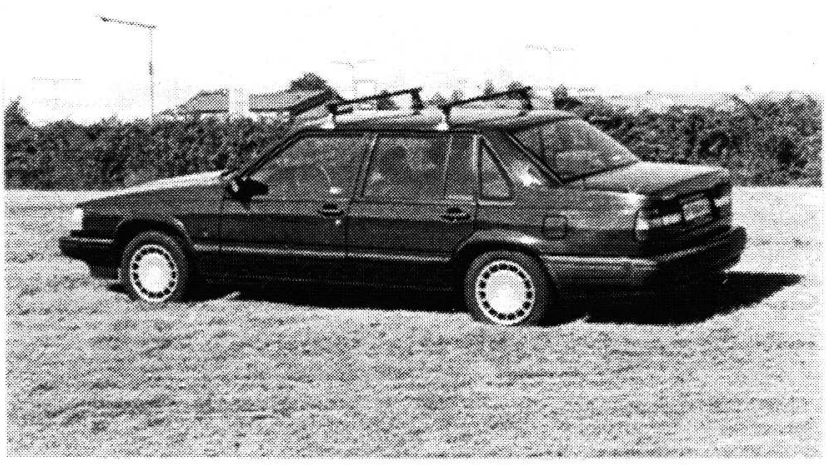

Figure 1. Experimental setup using roof-rack.

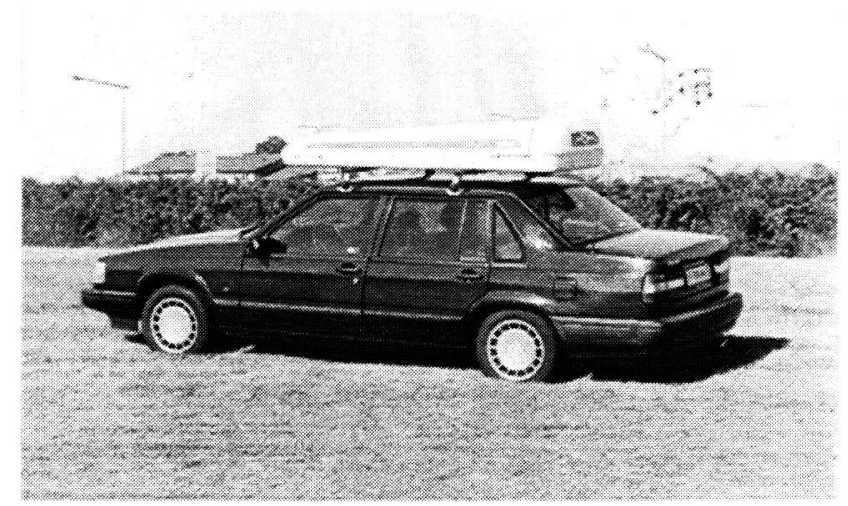

Figure 2. Experimental setup using ski-box.

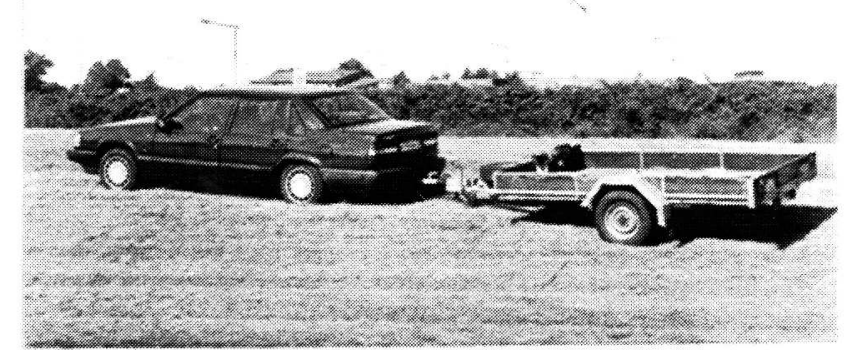

Figure 3. Experimental setup using trailer.

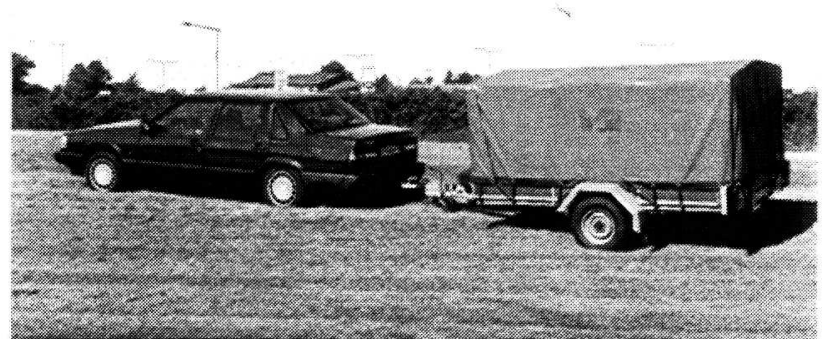

Figure 4. Experimental setup using trailer with cover. 
FUEL - Fuel consumption was obtained directly as the quotient between logged accumulated values of fuel flow and distance traveled. The fuel measurement results given in Tables $2-3$ are graphically presented by Figures 5-6. Lables and headings are explained by Table 1. The values are averages for six runs (three in each direction) of approximately $1200 \mathrm{~m}$ distance.

Table 2. Fuel consumption $(\mathrm{l} / \mathrm{km})$ using trailer in different configurations. No wind.

$\begin{array}{lccccc} & \text { Ref. } & \text { Trailer } & \mathrm{T}+\mathrm{L} & \mathrm{T}+\mathrm{C} & \mathrm{T}+\mathrm{L}+\mathrm{C} \\ 70 \mathrm{~km} / \mathrm{h} & 0.0696 & 0.0924 & 0.0952 & 0.1105 & 0.1181 \\ 80 \mathrm{~km} / \mathrm{h} & 0.0737 & 0.1006 & 0.1016 & 0.1249 & 0.1328 \\ 90 \mathrm{~km} / \mathrm{h} & 0.0787 & 0.1125 & 0.1141 & 0.1379 & 0.1437\end{array}$

Table 3. Fuel consumption $(l / \mathrm{km})$ using various equipment. Windy conditions.

$\begin{array}{lcccc} & \text { Ref. } & \text { Studs } & \text { Roof-rack } & \text { Ski-box } \\ 70 \mathrm{~km} / \mathrm{h} & 0.0689 & 0.0688 & 0.0707 & 0.0758 \\ 80 \mathrm{~km} / \mathrm{h} & 0.0745 & 0.0758 & 0.0760 & 0.0826 \\ 90 \mathrm{~km} / \mathrm{h} & 0.0790 & 0.0786 & 0.0799 & 0.0887\end{array}$

It can be deduced that all types of additional equipment investigated brought about raised fuel consumption for the tested vehicle. Likewise increased speed, in the interval $70-90 \mathrm{~km} / \mathrm{h}$, entailed raised fuel consumption. The increase is seen to be insignificant using studded tyres, $1-3 \%$ for an empty roof-rack, around $10 \%$ for a ski-box, $30-50 \%$ with a trailer and 60 $80 \%$ in configurations including a raised covered trailer. The effect from increased speed exhibited a similar sequence, a speed raise from $70 \mathrm{~km} / \mathrm{h}$ to $90 \mathrm{~km} / \mathrm{h}$ giving $13 \%$ higher fuel consumption in the reference case (no additional equipment) while, with the inclusion of a covered trailer, an increase of $25 \%$ in fuel consumption occurred when speed was increased from $70 \mathrm{~km} / \mathrm{h}$ to $90 \mathrm{~km} / \mathrm{h}$.

Tests in moderate $(4 \mathrm{~m} / \mathrm{s})$ side wind did not disclose any significant changes in fuel expenditure, when the results of corresponding wind/no wind experiments were compared.

It appears, not unexpectedly, that the trailer cover, implying considerably increased air resistance, and the trailer itself, which involves an additional wheel axle, cause the largest fuel consumption increases. The addition of weight in the form of extra load seems to be less important.

NITROGEN OXIDES - $\mathrm{NO}_{x}$ and $\mathrm{NO}$ mass emissions $(\mathrm{g} / \mathrm{km})$ were derived from the respective measured exhaust volume concentrations (ppm) and the known facts about fuel consumption, fuel composition and combustion stoichiometry [1] $(\lambda=1$ was presumed).

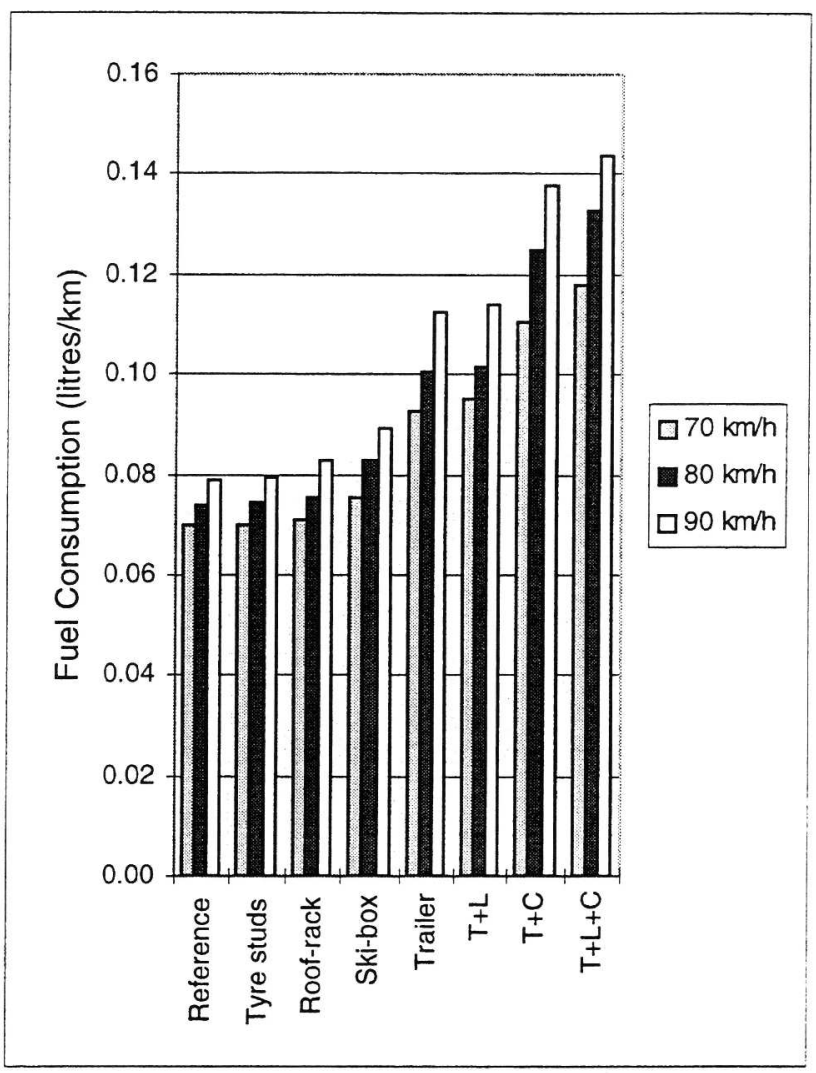

Figure 5. Fuel consumption $(\mathrm{l} / \mathrm{km})$ at different speeds using various equipment. No wind.

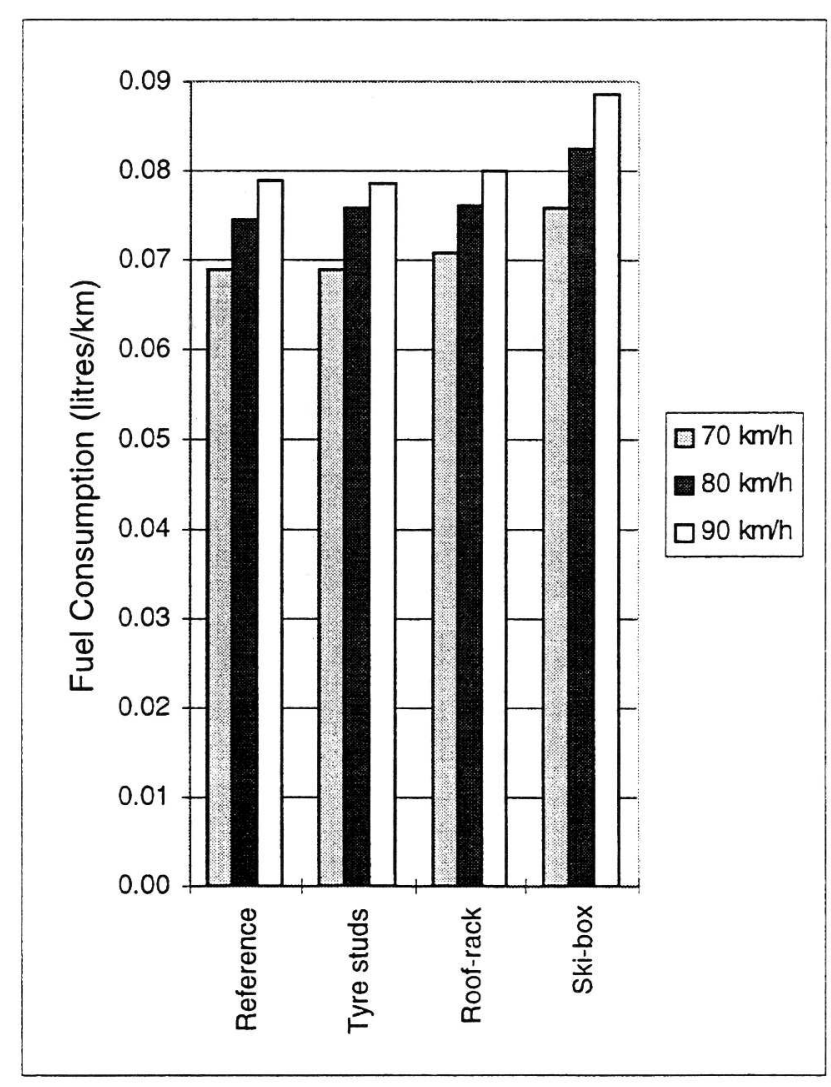

287 Figure 6. Fuel consumption $(l / \mathrm{km})$ at different speeds using various equipment. Windy conditions. 
Nitrogen dioxide ratios $\mathrm{NO}_{2} / \mathrm{NO}_{x}(\mathrm{v} / \mathrm{v})$ were determined as $\left(\left[\mathrm{NO}_{x}\right]-[\mathrm{NO}]\right) /\left[\mathrm{NO}_{x}\right]$, square brackets designating volume concentrations in the gas phase. Total nitrogen oxides $\mathrm{NO}_{x}(\mathrm{~g} / \mathrm{km})$ and $\mathrm{NO}_{2} / \mathrm{NO}_{x}$ volume fractions covering the same set of experimental conditions as before, are given by Tables 4-7 and Figures $7-8$. Estimated standard deviations (+/-\%) on $95 \%$ significance level are given in parentheses for $\mathrm{NO}_{2} / \mathrm{NO}_{x}$ (Tables 5 and 7 ).

Table 4. $\mathrm{NO}_{\mathrm{x}}$ emissions $(\mathrm{g} / \mathrm{km})$, using trailer in different configurations. No wind.

$\begin{array}{lccccc} & \text { Ref. } & \text { Trailer } & \mathrm{T}+\mathrm{L} & \mathrm{T}+\mathrm{C} & \mathrm{T}+\mathrm{L}+\mathrm{C} \\ 70 \mathrm{~km} / \mathrm{h} & 0.326 & 0.449 & 0.354 & 0.499 & 0.289 \\ 80 \mathrm{~km} / \mathrm{h} & 0.320 & 0.276 & 0.327 & 0.258 & 0.335 \\ 90 \mathrm{~km} / \mathrm{h} & 0.292 & 0.266 & 0.337 & 0.443 & 0.475\end{array}$

Table 5. $\mathrm{NO}_{2} / \mathrm{NO}_{\mathrm{x}}$ fractions ( $\left./ \mathrm{v}\right)$, using trailer in different configurations. No wind. ESDs in \%.

Ref. Trailer $\quad \mathrm{T}+\mathrm{L} \quad \mathrm{T}+\mathrm{C} \quad \mathrm{T}+\mathrm{L}+\mathrm{C}$ $70 \mathrm{~km} / \mathrm{h} 0.027(16) \quad 0.025(24) \quad 0.023(43) \quad 0.026(31) \quad 0.016(19)$ $\begin{array}{lllllll}80 \mathrm{~km} / \mathrm{h} & 0.025(20) & 0.025(36) & 0.023(43) & 0.026(27) & 0.017(41)\end{array}$ $90 \mathrm{~km} / \mathrm{h} \quad 0.025(20) \quad 0.022(40) \quad 0.022(40) \quad 0.025(36) \quad 0.016(25)$

Table 6. $\mathrm{NO}_{\mathrm{x}}$ emissions $(\mathrm{g} / \mathrm{km})$ at different speeds using various equipment. Windy conditions.

$\begin{array}{lcccc} & \text { Ref. } & \text { Studs } & \text { Roof-rack } & \text { Ski-box } \\ 70 \mathrm{~km} / \mathrm{h} & 0.323 & 0.299 & 0.302 & 0.362 \\ 80 \mathrm{~km} / \mathrm{h} & 0.323 & 0.299 & 0.347 & 0.379 \\ 90 \mathrm{~km} / \mathrm{h} & 0.340 & 0.350 & 0.305 & 0.297\end{array}$

Table 7. $\mathrm{NO}_{2} / \mathrm{NO}_{\mathrm{x}}$ fractions ( $/ \mathrm{v}$ ) at different speeds using various equipment. Windy conditions. ESDs in \%.

$\begin{array}{lcccc} & \text { Ref. } & \text { Studs } & \text { Roof-rack } & \text { Ski-box } \\ 70 \mathrm{~km} / \mathrm{h} & 0.011(18) & 0.012(24) & 0.010(30) & 0.019(16) \\ 80 \mathrm{~km} / \mathrm{h} & 0.009(22) & 0.013(38) & 0.012(17) & 0.020(25) \\ 90 \mathrm{~km} / \mathrm{h} & 0.011(27) & 0.013(38) & 0.013(31) & 0.020(35)\end{array}$

The test vehicle had been certified according to the Swedish A12 Regulation [16], allowing emission of $0.62 \mathrm{~g} / \mathrm{km}$ of $\mathrm{NO}_{x}$ during the Urban Driving Cycle (UDC) of the FTP, and $0.76 \mathrm{~g} / \mathrm{km} \mathrm{NO}_{x}$ during highway driving.

Although exhaust gas $\mathrm{NO}_{x}$ concentrations vary considerably in the course of a test at constant speed, the average mass emission values calculated for different cases are mostly close to $0.35 \mathrm{~g} / \mathrm{km}$ of $\mathrm{NO}_{\mathrm{x}}$, and seem to respond quite randomly or be indifferent to changes in speed as well as in additional equipment.

The nitrogen dioxide fraction of $\mathrm{NO}_{x}$ emitted by traffic is an important parameter to atmospheric pollution in urban areas $[17,18]$. The $\mathrm{NO}_{2} / \mathrm{NO}_{x}$ ratios cited in Tables 5 and 7 are in accord with values expected from a passenger car with TWC [19].

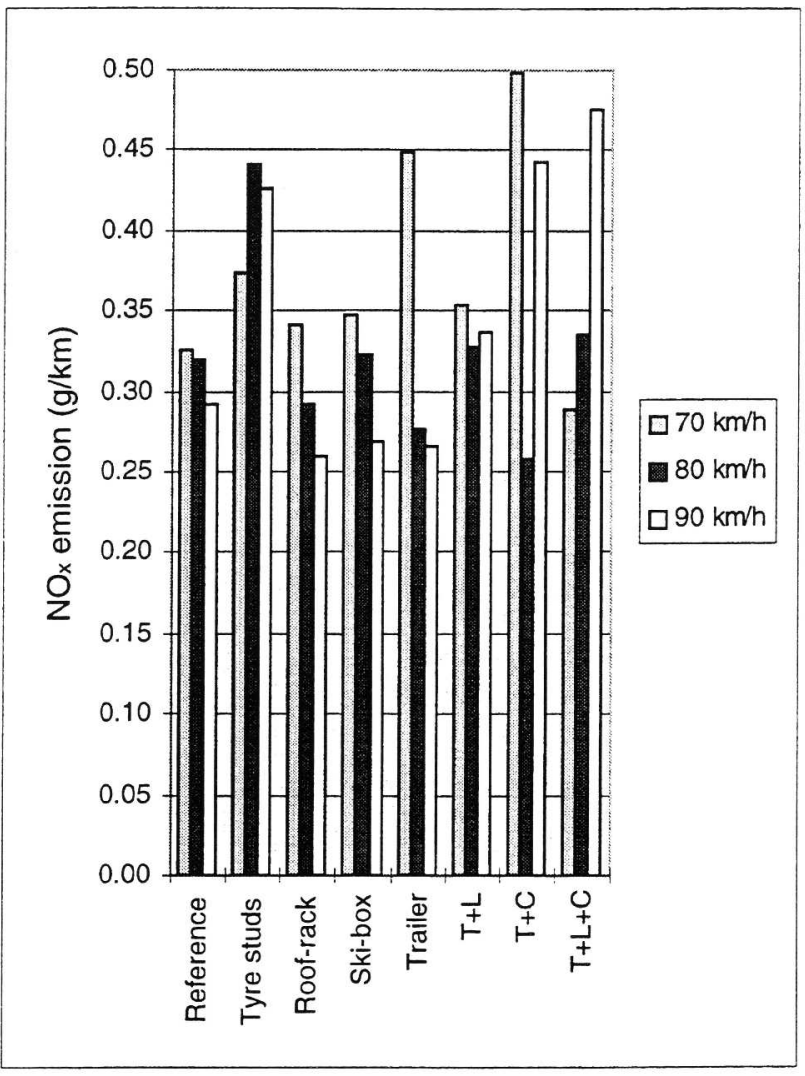

Figure 7. $\mathrm{NO}_{\mathrm{x}}$ emissions $(\mathrm{g} / \mathrm{km})$ at different speeds using various equipment. No wind.

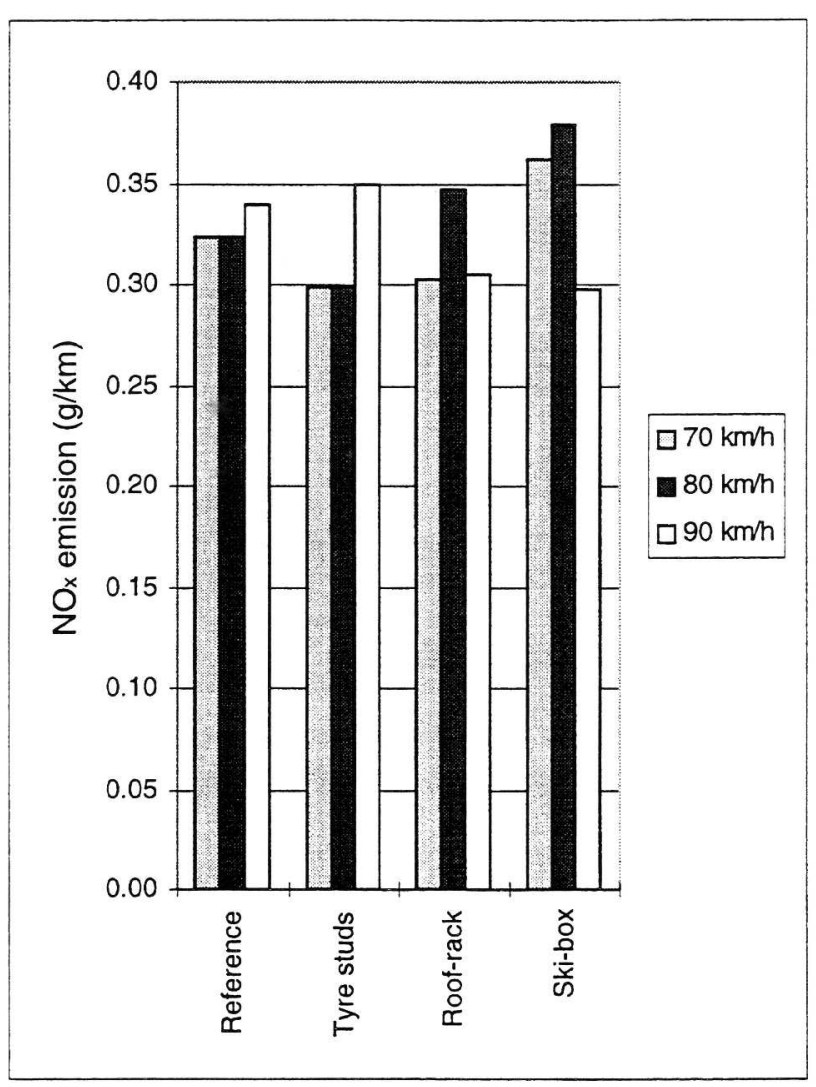

Figure 8. $\mathrm{NO}_{x}$ emissions $(\mathrm{g} / \mathrm{km})$ at different speeds 288 


\section{SUMMARY}

Fuel consumption and nitrogen oxides emissions for a passenger car were measured with on board instrumentation, at constant speeds on-the-road. Effects of using various kinds of peripheral equipment were studied.

Increased fuel consumption resulting from use of extra equipment was for roof-rack $1-3 \%$, for ski-box $10 \%$, for trailer $30-50 \%$ and for trailer with raised cover $60-80 \%$. Fuel consumption also rose with increased speed from $70 \mathrm{~km} / \mathrm{h}$ to $90 \mathrm{~km} / \mathrm{h}$, between $13 \%$ in the reference case (no extra equipment) and $25 \%$ (covered trailer with load). The use of tyre studs did not entail any significant change in fuel consumption, nor did occurrence of side wind $(4 \mathrm{~m} / \mathrm{s})$ during an experiment.

It was concluded that trailer (one extra wheel axle) and trailer cover (increased air resistance) cause the largest increases in fuel consumption. The addition of extra load has less effect.

Nitrogen oxides emissions did not relate in any systematic manner either to speed variations or to application of different kinds of extra equipment. Measured values for $\mathrm{NO}_{x}$ mass emissions averaged $0.35 \mathrm{~g} / \mathrm{km}$ and ranged from $0.25 \mathrm{~g} / \mathrm{km}$ to $0.5 \mathrm{~g} / \mathrm{km}$. No trends in $\mathrm{NO}_{x}$ emission due to use of trailer etc can be derived from the data. Calculated $\mathrm{NO}_{2} / \mathrm{NO}_{x}$ volume fractions were in the range 0.01-0.03, and although these values should be viewed with caution, due to the uncertainty introduced by subtraction ( $\left[\mathrm{NO}_{\mathrm{x}}\right]-[\mathrm{NO}]=\left[\mathrm{NO}_{2}\right]$ ) of two similar numbers, they agree well with previous findings.

\section{ACKNOWLEDGMENTS}

This work was sponsored by the Swedish Transport \& Communications Research Board, Contract KFB Dnr 1997-0125.

Participation by Mikael Bladlund, Ylva Matstoms and Janet Yakoub in the experiments and data processing is gratefully acklowledged.

\section{REFERENCES}

1. M. Lenner, "Measurement by On Board Apparatus of Passenger Cars' Real-World Exhaust Emissions and Fuel Consumption." Swedish Road and Transport Research Institute, VTI Meddelande 771A (1995).

2. J. Staab and D. Schürmann, "Measurement of Automobile Exhaust under Realistic Road Conditions." SAE Paper 871986 (1987)

3. D. Schürmann and J. Staab, "On-The-Road Measurements of Automotive Emissions." Sci. Total Environ. 93, 147-157 (1990).

4. G. Lenaers, "On-Board Real Life Emission Measurements on a 3 Way Catalyst Gasoline Car in Motor Way-, Rural- and City traffic and on Two Euro-1 Diesel City Buses." Sci. Total Environ. 189/190, 139-147 (1996).

5. R. A. Raub, "Removal of Roof-Mounted Emergency Lighting from Police Patrol Vehicles: An Evaluation." Transport Research Record 1047, 83-88 (1985).

6. J. H. Hansen and J. L. Blankenship, "Highway Patrol Light Bar Effects on Vehicle Fuel Efficiency." Transport Research Record 1059, 53-56 (1986).
7. C. H. Husz and H. Akins, "Optimizing Tire/Vehicle Relationships for Best Field Performance." SAE Paper 801021 (1980).

8. "Extra Luggage and Extra Fuel." Czechoslovak Motor Review 8, 1-5 (1976).

9. J. Yakoub, "Influence of a Camping Trailer on Passenger Car Fuel Consumption During Road Driving." Swedish Road and Transport Research Institute, VTI Notat 66 (1996).

10. N. A. Kelly and P. J. Groblicki, "Real-World Emissions from a Modern Production Vehicle Driven in Los Angeles." J. Air Waste Manage. Assoc. 43, 1351-1357 (1993).

11. J. C. Baily, B. Schmidl and M. L. Williams, "Speciated Hydrocarbon Emissions from Vehicles Operated over the Normal Speed Range on the Road." Atm. Env 24:1, 43-52 (1990).

12. J. C. Baily, K. Gunary, B. Schmidl and M. L. Williams, "Speciated Hydrocarbon Emissions from a Sample of UK Vehicles on the Road over a Range of Speeds." Sci. Total Environ. 93, 199-206 (1990).

13. D. R. Lawson, P. J. Groblicki, D. H. Stedman, G. A. Bishop and P. L. Guenther. "Emissions from In-Use Motor Vehicles in Los Angeles: A Pilot Study of Remote Sensing and the Inspection and Maintenance Program." J. Air Waste Manage. Assoc. 40, 1096 (1990).

14. Å. Sjödin and M. Lenner, "On-Road Measurements of Single Vehicle Pollutant Emissions, Speed and Acceleration for Large Fleets of Vehicles in Different Traffic Environments." Sci. Total Environ. 169, 157-165 (1995).

15. A. Sjödin, K. Andréasson, M. Wallin, M. Lenner and H. Wilhelmsson, "Identification of High-Emitting Catalyst Cars on the Road by Means of Remote Sensing." Int. J. of Vehicle Design 18:3/4, 326-329 (1997).

16. A12-Regulation. Concerning the Control of Air Pollution from Light Motor Vehicles. The Swedish Environmental Protection Agency Statute-Book, SNFS 1987:3 (1987).

17. J. C. Hilliard and R. W. Wheeler, "Nitrogen dioxide in Engine Exhaust." SAE paper 790691 (1979).

18. M. Lenner, O. Lindqvist and $\AA$. Rosén, "The NO/NO Ratio in Emissions from Gasoline-Powered Cars." Atm. Env. 17, 1395-1398 (1983).

19. M. Lenner, "Nitrogen Dioxide in Exhaust Emissions from Motor Vehicles." Atm. Env. 21, 37-43 (1987)

\section{DEFINITIONS, ACRONYMS, ABBREVIATIONS}

CVS Constant Volume Sample

ESD Estimated Standard Deviation

FEAT Fuel Efficiency Automobile Test

FTP Federal Test Procedure

GM General Motors

NO Nitrogen monoxide

$\mathrm{NO}_{2} \quad$ Nitrogen dioxide

$\mathrm{NO}$ * "Nitrogen oxides" $\left(\mathrm{NO}+\mathrm{NO}_{2}\right)$

TWC Three-Way Catalyst

UDC Urban Driving Cycle

VITO Flemish Institute for Technological Research, Belgium

VW Volkswagen 
VI FORSKAR FÖR ETT LIV I RÖRELSE

Statens väg- och transportforskningsinstitut (VTI) har kompetens och laboratorier för kvalificerade forskningsuppdrag inom transporter och samhällsekonomi, trafiksäkerhet, fordon, miljö samt för byggande, drift och underhăll av vägar och järnvägar.

The Swedish National Road and Transport Research Institute (VTI) has laboratories and know-how for advanced research commissions in transport and welfare economics, road safety, vehicles and the environment. It also has research capabilities for the construction, operation and maintenance of roads and railways.

\section{Adress}

Postal address

SE-581 95 Linköping, Sweden
Telefon

Telephone

Nat 013-20 4000

Int +4613204000
Fax

E-post

E-mail

Nat 013-14 1436

Int +4613141436 